\title{
THE GENUS AUSTROPOTAMOBIUS IN THE AUSSERFERN REGION (TYROL, AUSTRIA) WITH AN OVERLAP IN THE DISTRIBUTION OF A. TORRENTIUM AND A. PALLIPES POPULATIONS
}

\author{
D. SINT (1), J. DALLA VIA (2), L. FÜREDER (1)
}
(1) Institute of Ecology, University of Innsbruck, Technikerstraße25, 6020 Innsbruck, Austria. E-Mail: daniela.sint@uibk.ac.at
(2) Research Centre for Agriculture and Forestry Laimburg, 39040 Ora/Auer, Italy.

Reçu le 12 décembre 2005

Received December 12, 2005

Accepté le 12 janvier 2006

Accepted January 12, 2006

\begin{abstract}
Native populations of the stone crayfish Austropotamobius torrentium in Tyrol (Austria) are restricted to the region of Außerfern, where the lake "Haldensee" and the river "Archbach" are known to hold intact populations. Both records are of biogeographical importance because they are the southernmost located stock of the Bavarian-Tyrolean distribution area. In addition, the "Haldensee" is one of the highest locations holding stone crayfish in Austria. "Plansee", a lake within the Archbach catchment contains a dense population of Austropotamobius pallipes that was introduced about 80 years ago. During recent field surveys a gradual immigration of $A$. pallipes into the habitat populated by $A$. torrentium was noticed. We characterised the native populations of $A$. torrentium in Haldensee, its immediate outflow and in the river Archbach by means of population parameters and crayfish morphometry. The potential influence of the non-indigenous $A$. pallipes as intruder in the $A$. torrentium population is discussed.
\end{abstract}

Key-words: freshwater crayfish, habitat condition, migration barrier, hybridisation.

\section{LE GENRE AUSTROPOTAMOBIUS DANS LA RÉGION AUBERFERN (TYROL, AUTRICHE) AVEC UN RECOUVREMENT DE LA DISTRIBUTION DES POPULATIONS D'A. TORRENTIUM ET D'A. PALLIPES}

\section{RÉSUMÉ}

Les populations natives de l'écrevisse des torrents Austropotamobius torrentium au Tyrol (Autriche) sont limitées à la région de Außerfern, où le lac « Haldensee » et la rivière «Archbach » sont connus pour leurs populations bien conservées. Ces deux localités sont d'une importance biogéographique parce qu'elles contiennent le stock situé le plus au sud de l'aire de distribution Bavière-Tyrol. De plus, "Haldensee » est l'un des sites le plus élevé qui héberge des écrevisses des torrents en Autriche. "Plansee ", lac situé dans le basin d'Archbach contient une population dense d'Austropotamobius pallipes introduite il y a environ 80 ans. Au cours de récentes investigations sur le terrain, il a été observé une migration progressive d'A. pallipes vers I'habitat occupé par $A$. torrentium. Nous avons caractérisé les populations natives d'A. torrentium à Haldensee, dans son écoulement immédiat et dans la rivière Archbach par l'étude des paramètres de la population et la morphométrie des écrevisses. L'influence possible des écrevisses non indigènes A. pallipes en tant qu'intrus dans la population d'A. torrentium population est discutée.

Mots-clés : écrevisses, habitat, barrière de migration, hybridation. 


\section{INTRODUCTION}

The stone crayfish (Austropotamobius torrentium, Schrank, 1803) and the whiteclawed crayfish (Austropotamobius pallipes, Lereboullet, 1858) are highly endangered throughout Europe due to various reasons (e.g. FÜREDER, OBERKOFLER and MACHINO, 2002). A. pallipes inhabits freshwaters mainly in south-western and western Europe from Italy to Spain and the British Islands, whereas $A$. torrentium is naturally found east of the distribution area of $A$. pallipes with only small overlapping regions in the Balkan (HOLDICH, 2002). In Austria, A. torrentium is widely distributed in all provinces but A. pallipes was only recorded from two small regions - one each in Carinthia and Tyrol. In the Carinthian valleys Gitschtal and Gailtal several populations of the latter species were found (ALBRECHT, 1981; MACHINO and FÜREDER, 1996), and two populations were known within the Tyrolean region Außerfern (FÜREDER and MACHINO, 1996; FÜREDER and MACHINO, 1998). The species overlap in Tyrol is manmade as the white-clawed crayfish was introduced into the area some decades ago (FÜREDER and MACHINO, 1995). Individuals of this population were observed to invade the downstream population of $A$. torrentium despite several potential migration barriers (FÜREDER and MACHINO, 1996). The A. torrentium populations in Archbach and Haldensee are of great interest as they form the southernmost border of the species' Bavarian-Tyrolean distribution area and are the only records of stone crayfish in Tyrol (FÜREDER and HANEL, 2000).

Taking into account the still unclear species allocation of the A. pallipes complex and comparing the situation with that described in North America, where different species often are restricted to relatively small areas and show high potential for hybridisations when brought together (PERRY, FEDER and LODGE, 2001), this could also be possible within the genus Austropotamobius in Europe. Mixed populations of stone and noble crayfish (Astacus astacus, L.) are known from Bavaria (M. KELLER, pers. comm.), but other than within Austropotamobius, no hybridisation is expected between the different genera.

Because of the special situation of the co-occurrence of the two Austropotamobius species in a river in the region of Außerfern this study was carried out. Herein we characterise the populations from both species and investigate whether the actual situation poses threats to the native $A$. torrentium.

\section{MATERIAL AND METHODS}

\section{Study-area}

The region of Außerfern is situated in the north-western part of North Tyrol and is considered to originally been inhabited by the stone crayfish. Today crayfish populations occur in the following water bodies and sites:

\section{Haldensee (HAL) and its immediate outflow}

Haldensee lies in the Tannheimertal at an altitude of 1,124 $\mathrm{m}$ a.s.l. and holds one of the highest elevated crayfish populations in Tyrol (MACHINO and FÜREDER, 1998). It has a surface area of 72.7 ha and a maximum depth of 22 meter (TIROLER LANDESREGIERUNG, 2005). The first section of the Berger Ache, which is the only outlet in the north-western side of the lake, is populated by Austropotamobius torrentium. Along the northern side, the lake is bordered by a road, whereas the eastern shore is shallower and surrounded by meadows. Parts of the western shoreline are highly frequented by swimmers in summer. There only at a few spots, reed is providing for a more heterogeneous habitat. A forest reaches to the southern lakeshore, which in most areas is steeper and the bottom consists of rocks of varying size. Thus, shoreline and bottom substrate offer rich shelter for crayfish. This, together with the reed stands, is the only part of the lake where stone crayfish are found in the lake littoral. Scuba divers reported their presence also in deeper waters. In this study the animals from the lake as well as from the outlet are included. 


\section{Plansee (PLS)}

Plansee is a lake near the town of Reutte at $976 \mathrm{~m}$ a.s.l., it has a maximum depth of $78 \mathrm{~m}$ and is connected to the Heiterwanger See through a narrow channel. Both lakes have a combined surface area of 2,900 ha (TIROLER LANDESREGIERUNG, 2005) and are used to generate electricity from hydrodynamic power. FÜREDER (2002) recorded dense populations of Austropotamobius pallipes along the northern and eastern lakeshore of Plansee, whereas Heiterwanger See is inhabited by the same crayfish species, but at lower densities. These populations were founded through introduction, which probably took place around 1920 (FÜREDER and MACHINO, 1995).

\section{Archbach (ABU)}

The river Archbach is the outlet of Plansee and drains into the river Lech. The river continuum is interrupted several times, not only by the natural Stuiben Waterfalls, but also by retaining walls and power stations for hydropower generation. Even though considerable water-level fluctuations of up to about $1.5 \mathrm{~m}$ per day occur, the river is populated with $A$. torrentium near the village of Pflach $(840 \mathrm{~m})$ and several other river sections (FÜREDER L., unpubl. data). Above and below a hydropower dam crayfish were observed walking around in very shallow to almost no water during the night. Recently, this reach of the Archbach was modified by flood control measures, but habitat availability for crayfish was considered, and measures were defined to include effective shelter between rocks (FÜREDER L. unpubl. data).

\section{Hüttenmüh/see (HMS)}

Hüttenmühlsee is an impoundment within the river Archbach, formed by a retaining wall and lying upstream of the above mentioned stretch near Pflach. Some sections of the bank are affected by measures of flood protection, and like the areas further downstream, they offer a suitable habitat for crayfish. Some areas of the bottom are covered with Chara sp., which offers shelter for crayfish too. Daily water level fluctuations are generally less than $0.5 \mathrm{~m}$ in this area. Recently, an increasing number of $A$. pallipes was found within the native $A$. torrentium population in Hüttenmühlsee, especially in the upper parts of the water storage area (Table I).

\section{Table I}

Numbers of $A$. torrentium (AUT) and A. pallipes (AUP) and ratios of AUT/AUP caught in Hüttenmühlsee (HMS) and Archbach (ABU) in autumn 2004.

\section{Tableau I}

Nombre d'A. torrentium (AUT) et d'A. pallipes (AUP) ainsi que rapports des individus AUT/AUP capturés à Hüttenmühlsee (HMS) et Archbach (ABU) à l'automne 2004.

\begin{tabular}{ccccc}
\hline date & location & AUT & AUP & AUT / AUP \\
\hline 20.09 .2004 & HMS & 56 & 8 & 7 \\
14.10 .2004 & HMS & 29 & 13 & 2.23 \\
15.10 .2004 & HMS & 8 & 8 & 1 \\
21.09 .2004 & ABU & 33 & 1 & 33 \\
14.10 .2004 & ABU & 11 & 2 & 5.5 \\
\hline
\end{tabular}


Crayfish were caught during night hours by hand with the help of powerful spotlights. In addition baited traps were exposed overnight whenever it was possible. In Archbach and Hüttenmühlsee, both species $A$. torrentium and $A$. pallipes have been observed walking side by side and were found in one trap. This leads to the assumption that here both species share the same habitat.

\section{Morphometry}

A total number of 142 crayfish (37 specimens of $A$. torrentium from HAL, 30 A. pallipes from PLS, $33 A$. torrentium and $1 A$. pallipes from $\mathrm{ABU}, 33 \mathrm{~A}$. torrentium and 8 A. pallipes from HMS) was investigated for this study. For all individuals the following morphological characters were measured with a calliper to the nearest $0.1 \mathrm{~mm}$ : Claw length $(\mathrm{CLL})$, claw width $(\mathrm{CLW})$ and claw height $(\mathrm{CLH})$, length of the claw palm $(\mathrm{CPL})$, length of the claw finger (CFL), rostrum length (ROL) and rostrum width (ROW), head length (HEL) and head width (HEW), areola length (ARL) and areola width (ARW), abdomen length (ABL), abdomen width (ABW, at the second abdominal segment) and abdomen height $(A B H$, at the second abdominal segment), telson length (TEL) and telson width (TEW), carapace width (CPW), width at the cervical groove (CGW), width of the carapace at the hind edges (CEW), and carapace height (CPH, between the second and third pereopod) (Figure $1 \mathrm{~A}$ and $B$ ). Total length (TL) was measured to the nearest $1.0 \mathrm{~mm}$ by placing the crayfish in a stretched position on its back on scale paper. All bilateral parameters were measured on the right side except when injuries or regenerations were observed which chiefly affected the claws. In this case measurements were taken on the left side. Weight was recorded to the nearest $0.1 \mathrm{~g}$. Post orbital length (POL) was calculated as $\mathrm{HEL}+\mathrm{ARL}$, carapace length (CPL) as ROL + HEL + ARL. Beside these measurements, the sex and the number of injuries, counted as missing or injured claws, legs, antennae, carapace and abdomen, were recorded.

To avoid misleading comparisons between adults and juveniles, crayfish with TL less than $60 \mathrm{~mm}$ and $50 \mathrm{~mm}$ for $A$. pallipes and $A$. torrentium, respectively, were excluded from the analysis. These size limits were chosen based on observations in the field and on findings by GRANDJEAN et al. (1997) and STREISSL and HÖDL (2002). Males and females were analysed separately, as they are known to show sexual dimorphism (GRANDJEAN et al., 1997; GRANDJEAN and SOUTY-GROSSET, 2000; STREISSL and HÖDL, 2002).

Beside general population examinations, a stepwise multivariate discriminant analysis was performed. The size normalization procedure and selection of the relevant morphological characters was done as described in SINT, DALLA VIA and FÜREDER (2005). In addition, several ratios (e.g. claw length to claw width, CLL/CLW) were calculated and included in the analysis. The populations of Plansee (PLS) and Haldensee (HAL) were used to create a model for discriminating $A$. torrentium and $A$. pallipes which was then applied to the animals of the mixed populations of Archbach (ABU) and Hüttenmühlsee (HMS).

All the analyses were performed using Microsoft ${ }^{\circledR}$ Excel 2002, SP-2 and SPSS for Windows 11.0.1.

\section{RESULTS}

A total number of 148 crayfish (78 males and 70 females) was caught in autumn 2004. They consisted of 109 individuals of $A$. torrentium from three populations and 39 individuals of $A$. pallipes from 2 populations. Six specimens of $A$. torrentium from HAL had to be excluded due to a TL below $50 \mathrm{~mm}$, thus a valid number of 142 crayfish was used for the analyses.

The percentage of injured individuals was higher for females than for males and higher for $A$. torrentium than for $A$. pallipes. Within the females of $A$. pallipes $85.7 \%$ were 


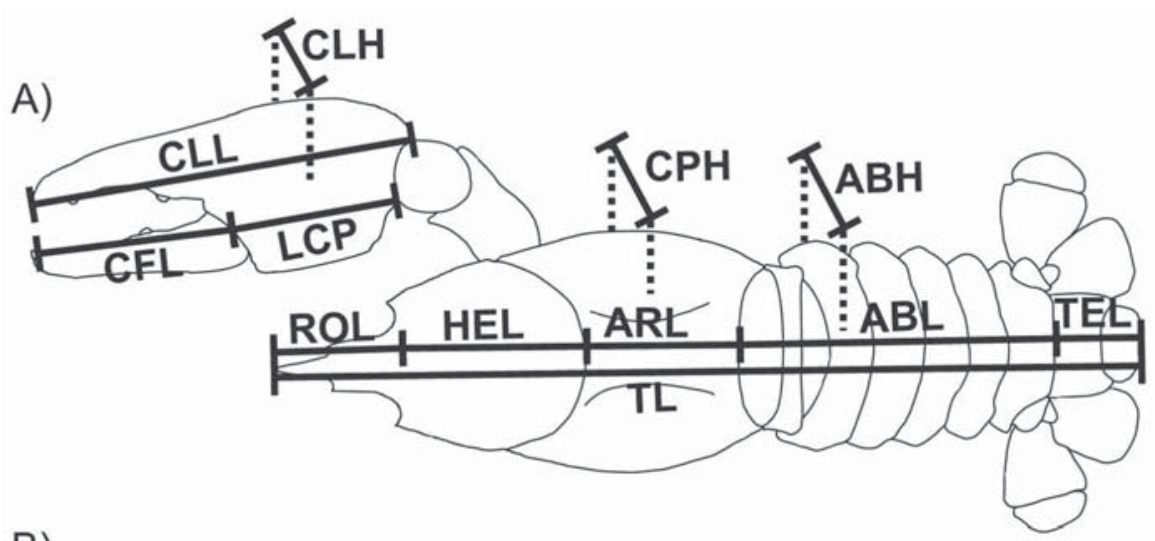

B)

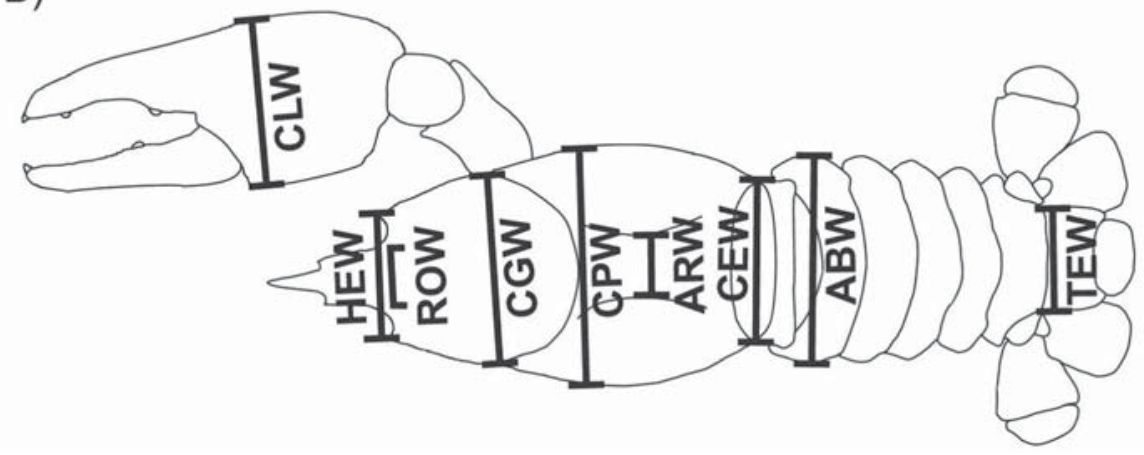

Figure 1

Position of performed measurements (measured lengths and heights $(A)$ and widths (B)). $A B H$ - abdomen height, $A B L$ - abdomen length, $A B W$ - abdomen width, ARL - areolar length, ARW - areolar width, CEW - width at the hind edges of the carapace, CFL - claw finger length, CGW - width at the cervical groove, CLH - claw height, CLL - Claw length, CLW - claw width, CPH - carapace height, CPW - carapace width, HEL - head length, HEW - head width, LCP - claw palm length, ROL - rostrum length, ROW - rostrum width, TEL - telson length, TEW - telson width, TL - total length.

\section{Figure 1}

Emplacement des mesures effectuées (longueur et hauteur (A) et largeurs (B)). $A B H$ - hauteur abdominale, ABL - longueur abdominale, ABW - largeur abdominale, ARL - longueur aréolaire, ARW - largeur aréolaire, CEW - largeur au fond du carapace, CFL - longueur du doigt de la pince, CGW - largeur au joint cervical, CLH - hauteur de la pince, CLL - longueur de la pince, CLW largeur de la pince, CPH - hauteur de la carapace, CPW - largeur de la carapace, HEL - longueur de la tête, HEW - largeur de la tête, LCP - longueur de la paume de la pince, ROL - longueur du rostre, ROW - largeur du rostre, TEL - longueur du telson, TEW - largeur du telson, TL - longueur totale.

injured in HMS and $76.5 \%$ in PLS, for males the rate of injured individuals was $54.5 \%$ in HMS and $66.1 \%$ in PLS. For A. torrentium the number of injured crayfish was highest in HMS (females: $73.3 \%$, males: $50.0 \%$ ) followed by HAL (females: $60.0 \%$, males: $38.1 \%$ ) and $\mathrm{ABU}$ (females: $40.0 \%$, males: $33.3 \%$ ).

Within the species, the females were not only more often injured but had also a higher number of injuries per individual, which was significant for $A$. torrentium $(p=0.001)$, 
but not for $A$. pallipes $(p=0.466)$. Between the species the mean number of injuries was higher for $A$. pallipes than for $A$. torrentium, but no significant difference was found, either for males $(p=0.071)$, or for females $(p=0.181)$ (Table II).

The ratio of $A$. torrentium to $A$. pallipes in the total catch clearly decreased from September to October for both locations with mixed populations (Table I).

The ratio of males to females showed only small differences between the crayfish populations. For stone crayfish it was between 0.95 in HAL and 1.20 in HMS and ABU. For white-clawed crayfish it was 1.14 in PLS and 1.67 in HMS (Table II).

Both sexes of $A$. pallipes showed higher TL, CLL and weight in HMS than in PLS, but only for the females the difference was significant $(p<0.001)$. Within the males of A. torrentium the individuals from HAL were significantly smaller (TL, CLL) and weighed less than those from HMS $(p \leq 0.001)$. The females from HAL differed in all three characters significantly from those from HMS $(p<0.001)$ and ABU $(p<0.05)$.

In the mixed populations, in all cases the means of TL, CLL and weight were higher for $A$. pallipes than for $A$. torrentium, but a statistically significant difference was only found for females $(p<0.001)$.

Within all populations of both species the highest average TL was found for individuals of $A$. pallipes from HMS (for males: $91.4 \mathrm{~mm}$; females: $88.7 \mathrm{~mm}$ ), and the

\section{Table II}

Numbers of males and females, sex ratio $(m / f)$, claw length $(C L L)$, total length (TL), weight and number of injuries of $A$. pallipes (AUP) populations from Plansee (PLS), Hüttenmühlsee (HMS) and Archbach (ABU), and of A.torrentium (AUT) populations from HMS, $A B U$ and Haldensee (HAL). Mean values and standard deviations for CLL, TL and weight as well as mean and standard errors of injuries are given.

\section{Tableau II}

Nombre de mâles et de femelles, sex ratio $(\mathrm{m} / \mathrm{f})$, longueur de la pince (CLL), longueur totale (TL), poids et nombre de blessures chez les populations d'A. pallipes (AUP) de Plansee (PLS), Hüttenmühlsee (HMS) et Archbach (ABU), ainsi que d'A. torrentium (AUT) de HMS, ABU et Haldensee (HAL). Les moyennes et leurs erreurs standard sont indiquées pour CLL, TL, le poids ainsi que pour les blessures.

\begin{tabular}{|c|c|c|c|c|c|c|c|c|}
\hline population & species & males & females & $m / f$ & CLL $(\mathrm{mm})$ & $\mathrm{TL}(\mathrm{mm})$ & weight (g) & injuries \\
\hline \multicolumn{9}{|l|}{ males } \\
\hline PLS & AUP & 16 & & 1.14 & $37.3(8.7)$ & $78.9(10.1)$ & $20.8(9.1)$ & $0.9(0.2)$ \\
\hline \multirow[t]{2}{*}{ HMS } & AUP & 5 & & 1.67 & $42.0(8.9)$ & $91.4(9.7)$ & $30.8(10.7)$ & $0.8(0.4)$ \\
\hline & AUT & 18 & & 1.20 & $36.5(8.3)$ & $78.4(10.6)$ & $21.9(10.1)$ & $0.5(0.2)$ \\
\hline \multirow[t]{2}{*}{$A B U$} & AUP & 0 & & --- & --- & --- & --- & --- \\
\hline & AUT & 18 & & 1.20 & $30.6(3.4)$ & $72.8(6.8)$ & $15.9(2.7)$ & $0.7(0.2)$ \\
\hline $\mathrm{HAL}$ & AUT & 21 & & 0.95 & $25.8(6.0)$ & $64.7(10.1)$ & $10.4(5.1)$ & $0.8(0.2)$ \\
\hline \multicolumn{9}{|l|}{ females } \\
\hline PLS & AUP & & 14 & 1.14 & $19.6(1.6)$ & $66.5(4.6)$ & $8.0(1.7)$ & $2.2(0.4)$ \\
\hline \multirow[t]{2}{*}{ HMS } & AUP & & 3 & 1.67 & $29.2(2.9)$ & 88.7 (4.9) & $19.9(2.6)$ & $1.3(0.9)$ \\
\hline & AUT & & 15 & 1.20 & $23.1(2.5)$ & $68.7(5.3)$ & $10.3(2.7)$ & $0.8(0.3)$ \\
\hline \multirow[t]{2}{*}{$A B U$} & AUP & & 1 & --- & 26.6 ( --- ) & 82.0 ( --- ) & 15.7 ( --- ) & $2.0(---)$ \\
\hline & AUT & & 15 & 1.20 & $21.5(1.9)$ & $64.9(4.3)$ & $8.6(1.8)$ & $0.9(0.2)$ \\
\hline $\mathrm{HAL}$ & AUT & & 22 & 0.95 & $18.2(1.9)$ & $58.1(5.2)$ & $6.6(1.7)$ & $0.8(0.3)$ \\
\hline
\end{tabular}


smallest in specimens from HAL (males: $64.7 \mathrm{~mm}$, females: $58.1 \mathrm{~mm}$ ). The highest mean CLL was also found in the A. pallipes population from HMS for males $(42.0 \mathrm{~mm})$ and females $(29.2 \mathrm{~mm})$, and the smallest in specimens of $A$. pallipes from HAL (males: $25.8 \mathrm{~mm}$, females: $18.2 \mathrm{~mm}$; Table II, Figure 2A).

The weight was strongly correlated to TL and CLL $\left(r^{2}>0.9, p<0.01\right)$. As a consequence, for white-clawed crayfish it was highest in HMS and lowest in HAL.

The ratio of CPL: CPH was significantly higher for both sexes in $A$. torrentium than in $A$. pallipes $(p<0.001)$ (Figure $2 B)$.

Multivariate discriminant analysis was well suited to distinguish A. pallipes from A. torrentium. $100 \%$ of the original and of the cross-validated cases from PLS and HAL were correctly classified and the eigenvalues were high (27.5 for males, 37.9 for females). The derived model was based on different morphological characters for males and females, these were CLL, ABB, CLL/CLW, CLL/CFL, ARL/ARW for males and CFL/ CPL, ROL/ROW, ARL/ARW, CPL/CPH, TEL/TEW and TL/CPL for females. Details on the loadings are given in Table III.

When the frequency of discriminant values was plotted for all four populations, two well-separated groups corresponding to the two species became visible around the centroids (males: 4.376 and -5.835 , females: 5.929 and -5.929 ), with only a few crayfish in-between for both sexes (Figure 3).
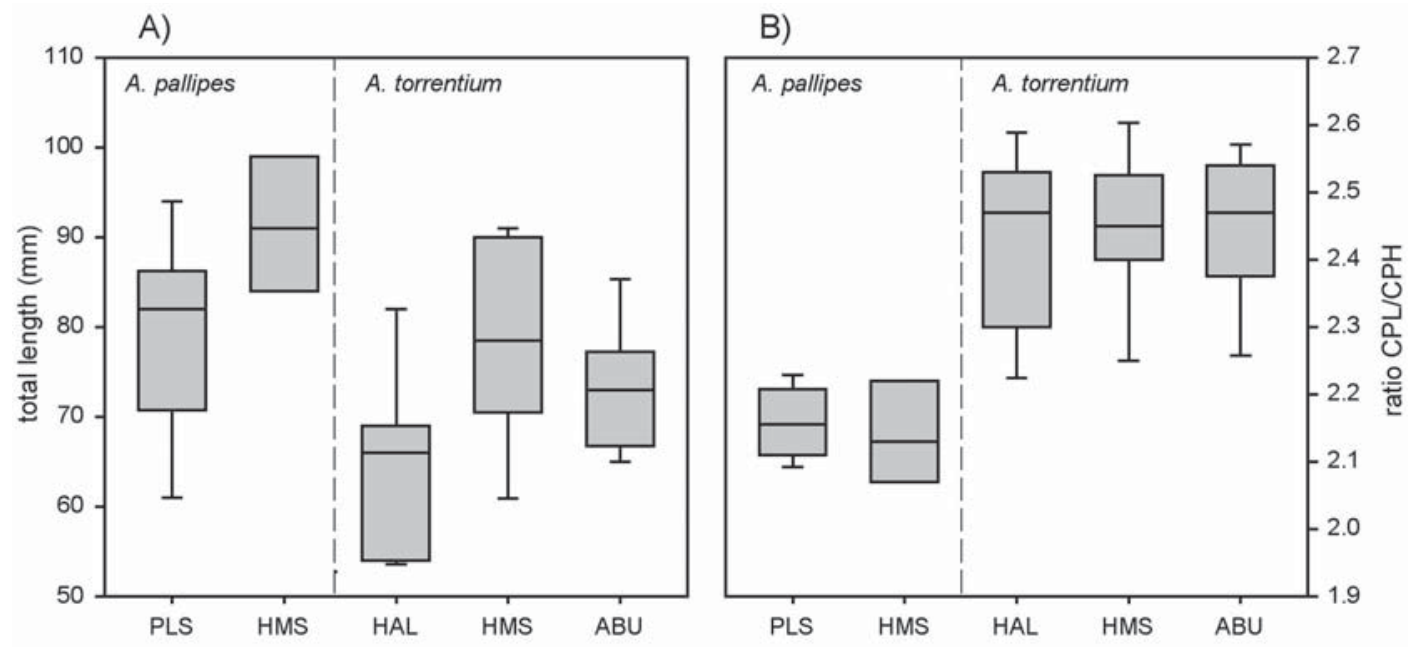

Figure 2

Box plots (median [line], quartiles [box], $10^{\text {th }}$ and $90^{\text {th }}$ percentiles [whiskers]) of the total length $(A)$ and the ratio of carapace length to carapace height (CPL/ $\mathrm{CPH}$ ) (B) of male crayfish individuals in Plansee (PLS), Hüttenmühlsee (HMS), Haldensee (HAL) and Archbach (ABU).

Figure 2

Diagrammes en boîtes (Boxplots) (médianes, quartiles, $10^{\circ}$ et $90^{\circ}$ percentiles) de la longueur totale (A) et rapport de la longueur de la carapace sur la hauteur de la carapace (CPL/CPH) (B) des individus mâles collectés à Plansee (PLS), Hüttenmühlsee (HMS), Haldensee (HAL) et Archbach (ABU). 


\section{Table III}

Discriminant Analysis: Standardized canonical discriminant function coefficients for males and females for the morphological parameters (see Figure 2A for location). Eigenvalue, and canonical correlation coefficient (ccc) are given.

\section{Tableau III}

Analyse discriminante: Coefficients canoniques standardisés concernant les mâles et les femelles pour les paramètres morphologiques (voir Figure 2A). Les valeurs individuelles et les coefficients de corrélation canonique (ccc) sont indiqués.

\begin{tabular}{lcllc}
\hline \multicolumn{2}{c}{ males } & & \multicolumn{2}{c}{ females } \\
\cline { 5 - 5 } morphol. & $\begin{array}{c}\text { discriminant } \\
\text { function }\end{array}$ & & $\begin{array}{l}\text { morphol. } \\
\text { parameter }\end{array}$ & $\begin{array}{c}\text { discriminant } \\
\text { function }\end{array}$ \\
\hline CLL & 1.036 & & CFL / CPL & -0.509 \\
ABW & 0.921 & & ROL / ROW & 1.076 \\
CLL / CLW & 1.114 & & ARL / ARW & -0.768 \\
CLL / CFL & 0.832 & & CPL / CPH & -0.890 \\
ARL / ARW & -0.939 & & TEL / TEW & 1.401 \\
& & & TL / CPL & 0.727 \\
\cline { 5 - 5 } eigenvalue & 27.502 & & eigenvalue & 37.855 \\
ccc & 0.982 & & ccc & 0.987 \\
\hline
\end{tabular}

\section{DISCUSSION}

It is well known that differences in crayfish morphology may occur not only on the level of species but also between distinct populations, caused by adaptations to local environmental conditions (GRANDJEAN and SOUTY-GROSSET, 2000; SINT, DALLA VIA and FÜREDER, 2005).

In this study, both surveyed species Austropotamobius pallipes and A.torrentium had smaller individuals at higher elevation (PLS and HAL). This may be attributed to the cooler water temperatures resulting in a shorter active phase and therefore also shorter period of growth during the summer months. This becomes apparent in Haldensee, where the water temperature was about 1.5 to $2^{\circ} \mathrm{C}$ lower than in Archbach and Hüttenmühlsee at every measurement. This hypothesis is also supported by the fact that we found very small egg-bearing females of $A$. torrentium in June (TL min $46 \mathrm{~mm}$; mean $58 \mathrm{~mm}$ ), while STREISSL and HÖDL (2002) reported the onset of maturity for stone crayfish females in the size class of 59-65 mm. Intraspecific size differences could be disregarded because all data were normalized for size and small animals were excluded from statistical analysis in order to assure comparisons only between mature crayfish. The observed size differences between $A$. torrentium and $A$. pallipes were expected, because it is well known that A. pallipes can reach a TL of up to $12 \mathrm{~cm}$ (MACHINO et al., 2004; HAGER, 1996) while A. torrentium reaches only about $10 \mathrm{~cm}$ (HAGER, 1996).

The sex-ratio was found to be close to 1 in all populations, which corresponds well to former findings (STREISSL and HÖDL, 2002; GRANDJEAN and SOUTY-GROSSET, 2000).

Although individuals of $A$. pallipes were larger than those of $A$.torrentium, they had more non-lethal injuries than the latter in the mixed populations from ABU and HMS 


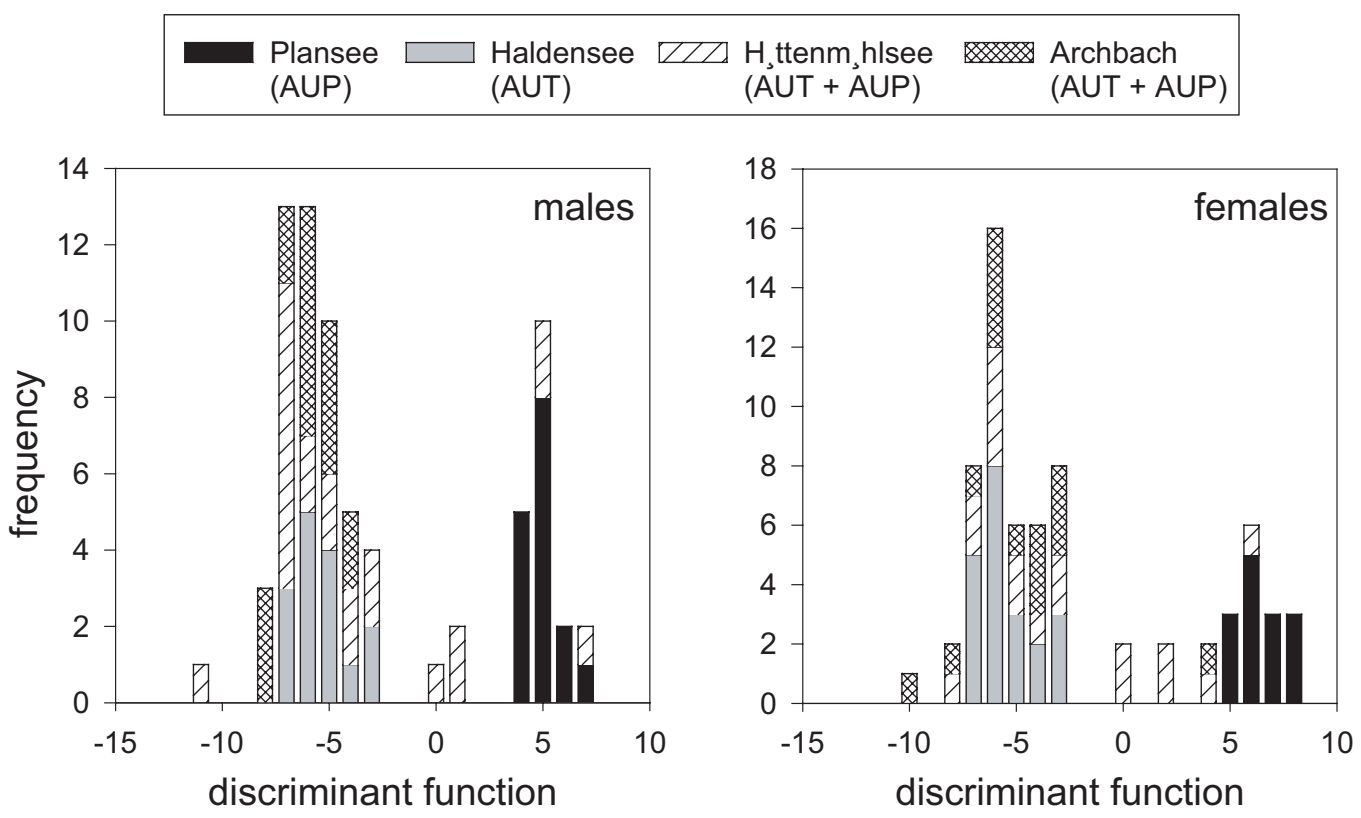

Figure 3

Discrimination between the two species Austropotamobius pallipes (AUP) and A. torrentium (AUT) out of 4 populations by the discriminant functions for males and females. Populations with only one species (Plansee and Haldensee) were used to create a discrimination model to divide the two species. This model was then applied to individuals of the mixed populations in Archbach and Hüttenmühlsee. See Table III for details on the discriminant functions.

\section{Figure 3}

Discrimination entre Austropotamobius pallipes (AUP) et $A$. torrentium (AUT) pour 4 populations par les fonctions discriminantes chez les mâles et chez les femelles. Des populations avec seulement une espèce (Plansee et Haldensee) ont été utilisées pour créer un modèle de discrimination pour diviser les deux espèces. Cemodèle a étéalors appliqué aux individus des populations mélangées dans Archbach et Hüttenmühlsee. Voir le Tableau III pour les détails portant sur les fonctions discriminantes.

(Table II). This could indicate the occurrence of altered inter- or intraspecific competition (STUCKI and ROMER, 2001). Different crayfish species are known to have different aggression potentials (WESTMAN and SAVOLAINEN, 2001; VORBURGER and RIBI, 1999; FURRER, CANTIENI and DUVOISIN, 1999; SÖDERBÄCK, 1995), but up to now no comparative investigations dealing with the aggression potentials of $A$. pallipes and A. torrentium living in the same habitat have been performed. According to the findings of VORBURGER and RIBI (1999), A. torrentium is able to exclude even larger specimens of the signal crayfish (Pacifastacus leniusculus, (Dana, 1852)) from shelter and may show a generally more aggressive behaviour than the latter. Thus, the greater number of injuries observed on white-clawed crayfish in HMS could well be due to interspecific competition with stone crayfish. This relatively higher aggression of $A$. torrentium is also supported by observations during field work where they showed much more aggressive behaviour towards the researchers' hands during handling than did white-clawed or noble crayfish.

However, the increasing numbers of $A$. pallipes in Hüttenmühlsee - as has been found recently - argue against such an interspecific dominance of $A$. torrentium. This points to the possibility that in this particular case $A$. pallipes may have an advantage, 
probably due to its larger size, since dominance is strongly connected to total length and aggressive interactions are mainly found between equal sized crayfish (VORBURGER and $\mathrm{RIBI}, 1999)$.

The results of the multivariate discriminant analysis allow a very good distinction between $A$. pallipes and $A$. torrentium as the variation between the two species is higher than the within species variation needed for distinction (BÜHL and ZÖFEL, 2002; HAIR et al., 1998). This was also found for the differentiation between $A$. pallipes and $A$. astacus (SINT, DALLA VIA and FÜREDER, 2005). However, there is also a small number of individuals with a discriminant value around zero for both sexes (Figure 3 ) and they could not be allocated to one of the two species with absolute certainty. This is confirmed by the fact that in some cases it was not easy to determine the exact species during fieldwork. According to CESARONI, ALLEGRUCCI and SBORDONI (1992) as well as PERRY, FEDER and LODGE (2001) hybrids are known to show morphological characters of both parental species, but no information is available about hybridisation between $A$. torrentium and $A$. pallipes. Interbreedings have already been reported for the genera Astacus (FURRER, CANTIENI and DUVOISIN, 1999), Orconectes (PERRY, FEDER and LODGE, 2001; PERRY et al., 2001) and Procambarus (CESARONI, ALLEGRUCCI and SBORDONI, 1992) although in some cases the outcome of the mating between two different species is not clear. While FURRER, CANTIENI and DUVOISIN (1999) reported hybrids between $A$. leptodactylus females and $A$. astacus males with a slightly altered chela shape, they did not find any surviving offspring when $A$. astacus females were paired with $A$. leptodactylus males. Astacus astacus was also observed to mate with Pacifastacus leniusculus, but this did not result in viable offspring (SÖDERBÄCK, 1995).

Hybridisation is considered to be one of the main threats to endangered species - the more, the closer related the parental species are (PERRY, LODGE and FEDER, 2002; RHYMER and SIMBERLOFF, 1996). So in North America, where the rusty crayfish (Orconectes rusticus (Girard, 1852) was originally restricted to the tributaries of the Ohio River; today it is displacing O. propinquus (Girard, 1852) and O. virilis (Hagen, 1870) due to hybridisation and competition, wherever it was introduced by man (PERRY, LODGE and FEDER, 2002; PERRY et al., 2001). So the invasion of potential competitors may pose an additional threat to the autochthonous stone crayfish.

Thus, it is of fundamental importance to know whether these two species can coexist and whether hybrids are generated, e.g. in Archbach, because only few populations of A. torrentium still exist in Tyrol (FÜREDER and MACHINO, 1996; FÜREDER and MACHINO, 1999). Hydropower development, habitat degradation and river engineering have substantially contributed to the decline of this endangered crayfish species in the region. Conservation measures that have recently been implemented, may improve the situation (FÜREDER L. unpubl. data). In the necessary flood protection measures at several river sections activities to extend and improve the crayfish habitat were included. A larger area with side channels offering heterogeneous aquatic habitats were considered in the river management plan. How the situation further develops highly depends on the close collaboration between water district managers, river engineers and nature conservation authorities.

\section{ACKNOWLEDGEMENTS}

We appreciate the help of Michaela Salcher, Christian Berger and Christine Rangger for field work assistance and Astrid Flandorfer for reading the manuscript. Funding was provided by the InterregllIA program of the EU (Project "CrayfishGeneflow"), the Tiroler Landesregierung and the Autonomous Province of Bozen/ Bolzano. 


\section{REFERENCES}

ALBRECHT H., 1981. Die Flusskrebse des westlichen Kärnten. Carinthia II, 1, 267-274.

BÜHL A., ZÖFEL P., 2002. SPSS 11. Einführung in die moderne Datenanalyse unter Windows. 8. überarbeitete u. erweiterte Auflage. Pearson Education Deutschland $\mathrm{GmbH}$, München, $757 \mathrm{p}$.

CESARONI D., ALLEGRUCCI G., SBORDONI V., 1992. A narrow hybrid zone between two crayfish species from a Mexican cave. Journal of Evolutionary Biology, 5, 643659.

FÜREDER L., 2002. Flusskrebse in Tirol: Vorkommen, Verbreitung, ökologische Bedeutung und Gefährdung. - Natur in Tirol, Band 10. Naturkundliche Beiträge der Abteilung Umweltschutz, Innsbruck, 130 p.

FÜREDER L., HANEL R., 2000. Flusskrebse in den Gewässern Nord- und Osttirols: Verbreitung, ökologische Bedeutung und Schutzmaßnahmen. Berichte des naturwissenschaftlich-medizinischen Vereins in Innsbruck, 87, 221-241.

FÜREDER L., MACHINO Y., 1995. Record of the white-clawed crayfish Austropotamobius pallipes (Lereboullet 1858) from Plansee (Tyrol, Austria.). Berichte des naturwissenschaftlich-medizinischen Vereins in Innsbruck, 82, 241-246.

FÜREDER L., MACHINO Y., 1996. Das letzte natürliche Vorkommen des Steinkrebses Austropotamobius torrentium (Schrank, 1803) in Tirol. Berichte des naturwissenschaftlich-medizinischen Vereins in Innsbruck, 83, 211-219.

FÜREDER L., MACHINO Y., 1998. Verbreitung von Flußkrebsen in Tirol, Südtirol und Vorarlberg. Stapfia, 58, 77-88.

FÜREDER L., MACHINO Y., 1999. Past and Present Crayfish Situations in Tyrol (Austria). Freshwater Crayfish, 12, 751-764.

FÜREDER L., OBERKOFLER B., MACHINO Y., 2002. Flusskrebse in den Gewässern Südtirols: Verbreitung, ökologische Bedeutung und Gefährdung. Berichte des naturwissenschaftlich-medizinischen Vereins in Innsbruck, 89, 179-199.

FURRER S., CANTIENI M., DUVOISIN N., 1999. Freshly hatched hybrids between Astacus astacus and Astacus leptodactylus differ in chela shape from purebred offspring. Freshwater crayfish, 12, 90-97.

GRANDJEAN F., ROMAIN D., AVILA-ZARZA C., BRAMARD M., SOUTY-GROSSET C., MOCQUARD J.P., 1997. Morphometry, sexual dimorphism and size at maturity of the white-clawed crayfish Austropotamobius pallipes pallipes (Lereboullet) from a wild French population at Deux-Sèvres (Decapoda, Astacidea). Crustaceana, 70 (1), 31-44.

GRANDJEAN F., SOUTY-GROSSET C., 2000. Genetic and morphological variation in the endangered crayfish species, Austropotamobius pallipes (Lereboullet) (Crustacea, Astacidae) from the Poitou-Charentes region (France). Aquatic Sciences, 62, 1-19.

HAGER J., 1996. Edelkrebse. Biologie - Zucht - Bewirtschaftung. Leopold Stocker Verlag, Graz, $128 \mathrm{p}$.

HAIR J.F. JR, ANDERSON R.E., TATHAM R.L., BLACK W.C., 1998. Multivariate Data Analysis. $5^{\text {th }}$ Edition. Prentice-Hall Inc., New Jersey. XX $+730+12 p$.

HOLDICH D.M., 2002. Distribution of crayfish in Europe and some adjoining countries. Bull. Fr. Pêche Piscic., 367, 611-650.

MACHINO Y., FÜREDER L., 1996. Der Kärntner "Sumpfkrebs" im Gailtal. Österreichs Fischerei, 49 (4), 93-97. 
MACHINO Y., FÜREDER L., 1998. Der Steinkrebs Austropotamobius torrentium (Schrank, 1803) im Haldensee (Tirol, Österreich) und weitere Nachweise von Flußkrebsen in hochgelegenen Gewässern. Berichte des naturwissenschaftlich-medizinischen Vereins in Innsbruck, 85, 223-229.

MACHINO Y., FÜREDER L., LAURENT P.J., PETUTSCHNIG J., 2004. Introduction of the white-clawed crayfish Austropotamobius pallipes in Europe. Berichte des naturwissenschaftlich-medizinischen Vereins in Innsbruck, 91, 187-212.

PERRY W.L., FEDER J.L., GWYER G., LODGE D.M., 2001. Hybrid zone dynamics and species replacement between Orconectes crayfishes in a northern Wisconsin lake. Evolution, 55 (6), 1153-1160.

PERRY W.L., FEDER J.L., LODGE D.M., 2001. Implications of hybridization between introduced and resident Orconectes crayfishes. Conservation Biology, 15 (6), 16561666.

PERRY W.L., LODGE D.M., FEDER J.L., 2002. Importance of hybridisation between indigenous and nonindigenous freshwater species: An overlooked thread to North American biodiversity. Systematic Biology, 51 (2), 255-275.

RHYMER J.M., SIMBERLOFF D., 1996. Extinction by hybridization and introgression. Annual Review of Ecology, Evolution and Systematics, 27, 83-109.

SINT D., DALLA VIA J., FÜREDER L., 2005. Morphological variations in Astacus astacus L. and Austropotamobius pallipes (Lereboullet) populations. Bull. Fr. Pêche Piscic, 376-377, 637-652.

SÖDERBÄCK B., 1995. Replacement of the native crayfish Astacus astacus by the introduced species Pacifastacus leniusculus in a Swedish lake: possible causes and mechanisms. Freshwater Biology, 33, 291-304.

STREISSL F., HÖDL W., 2002. Growth, morphometrics, size at maturity, sexual dimorphism and condition index of Austropotamobius torrentium Schrank. Hydrobiologia, 477, 201-208.

STUCKI T., ROMER J., 2001. Will Astacus leptodactylus displace Astacus astacus and Austropotamobius torrentium in Lake Ägeri, Switzerland? Aquatic Sciences, 63, 477-489.

TIROLER LANDESREGIERUNG, Abt. Wasserwirtschaft, 2005. Badegewässer in Tirol. http://www.tirol.gv.at/themen/umwelt/wasser/fluesseundseen/badegewaesser/ badegewaesser_badesstellen.shtml. 18.05.2005.

VORBURGER C., RIBI G., 1999. Aggression and competition for shelter between a native and an introduced crayfish in Europe. Freshwater Biology, 42, 111-119.

WESTMAN K., SAVOLAINEN R., 2001. Long term study of competition between two co-occurring crayfish species, the native Astacus astacus L. and the introduced Pacifastacus leniusculus Dana, in a Finnish lake. Bull. Fr. Pêche Piscic., 361, 613627. 